\title{
26. ORGANIC CARBON, REDUCED SULFUR, AND IRON RELATIONSHIPS IN SEDIMENTS OF THE PERU MARGIN, SITES 680 AND $688^{1}$
}

\author{
Kay-Christian Emeis ${ }^{2}$ and John W. Morse ${ }^{3}$
}

\begin{abstract}
Organic-carbon-rich anoxic sediments from the continental shelf (Site 680) and the lower continental slope (Site 688 ) off Peru were studied to determine factors controlling the accumulation of reduced sulfur. High concentrations of organic matter in diatomaceous muds, its thermal immaturity, and the presence of abundant hydrogen-containing organic compounds lead to the conclusion that organic matter is not limiting for reduced sulfur formation. Rather, high degrees of iron pyritization at Site 680 limit pyrite accumulation in sediments from this shelf site. The low degree of iron pyritization and nearly complete reduction of dissolved sulfate at Site 688 suggest that a lack of interstitial sulfate is limiting pyrite formation there. Although factors that limit the formation of sedimentary iron sulfide are different at each site, the resulting average reduced-sulfur concentrations are remarkably similar $(0.85$ wt.\% at Site 680 and 0.86 wt.\% at Site 688$)$. Carbon to sulfur (C/S) ratios are higher in samples containing in excess of $3 \mathrm{wt} . \%$ organic carbon than the average of 2.8 in normal marine sediments and have been primarily influenced by variations in organic matter concentrations.
\end{abstract}

\section{INTRODUCTION}

Bacterially mediated reduction of sulfate during oxidation of organic matter in marine sediments results in the production of hydrogen sulfide. A portion of the reduced sulfur is retained in iron sulfide minerals until the sediment has been exposed to weathering. Although the processes of sulfate reduction and pyrite formation are complex (e.g., Berner, 1984,1985 ), the relationship between concentrations of organic carbon and total reduced sulfur has been used to interpret paleoenvironments (e.g., Berner and Raiswell, 1983, 1984; Leventhal, 1983; Davison et al., 1985; Raiswell and Berner, 1985).

Three major types of environments may be discerned from the weight ratio of total organic carbon (TOC) to total reduced sulfur (TRS). Briefly, normal marine sediments have a ratio of about 2.8, while freshwater environments are expected to have higher ratios because of a lack of sulfate, and depressed $\mathrm{C} / \mathrm{S}$ ratios are ascribed to anoxic environments, where sulfide is produced in the water column. However, a number of factors have emerged in some studies that complicate or invalidate the use of $\mathrm{C} / \mathrm{S}$ ratios in paleoenvironmental reconstructions. These factors include (1) post-depositional mobility of reactive components (e.g., Berner, 1969; Morse et al., unpubl. data), (2) limitation of iron sulfide formation because of limitations in the available "reactive" iron (e.g., Canfield, 1988), (3) variations in the type of organic matter (e.g., Westrich and Berner, 1984), and (4) loss of organic matter during thermal maturation (Raiswell and Berner, 1987). In addition, this approach to environmental reconstruction seems questionable in sediments that are both low $(<1 \mathrm{wt} . \%$ TOC; Raiswell and Berner, 1985) and high (>3 wt.\% TOC; Morse et al., unpubl. data) in organic carbon.

The primary objective of this study is to determine the relationship of TOC to TRS in sediments from the Peru

\footnotetext{
${ }^{1}$ Suess, E., von Huene, R., et al., 1990. Proc. ODP, Sci. Results, 112: College Station, TX (Ocean Drilling Program). 77840.

Ocean Drilling Program, 1000 Discovery Drive, College Station, TX

${ }^{3}$ Department of Oceanography, Texas A\&M University, College Station, TX 77848 .
}

upwelling area, as well as outline the factors that influence this ratio. The sediments of forearc basins on the shelf and slope are unusually rich in organic matter of marine origin (e.g., Powell et al., this volume), accumulate at high rates (in excess of $40 \mathrm{~m} / \mathrm{m} . y$.), and are thermally immature. Seifert et al. (this volume) found that carbon in amino compounds and carbohydrates-excellent substrates for bacterial metabolismamount to a minimum of approximately $2 \%$ of TOC at depths below 20 meters below seafloor (mbsf), after decreasing rapidly from approximately $20 \%$ at the sediment/water interface. The experimental results of Parkes et al. (this volume) on microbial reduction of radio-labeled sulfate in samples from 90 mbsf further show that organic matter in the Quaternary diatomaceous muds and oozes from the shelf and upper slope is labile and contains abundant degradable substrate.

Added interest comes from the discovery of unusual subsurface hydrology in the study area (Kastner et al., this volume), which could pertain to the formation of reduced sulfur minerals. Our study complements earlier investigations of TRS in immature marine sediments from the Benguela upwelling system and the Tyrrhenian Sea (Morse et al., unpubl. data).

\section{Geological and Depositional Settings of Sites 680 and 688}

We chose to investigate Ocean Drilling Program (ODP) Sites 680 and 688, drilled during Leg 112, because the sediments recovered there conform to deposits of primary upwelling-related deposition on the shelf (Site 680) and to the secondary depositional center on the lower slope, where material that was resuspended on the shelf and upper slope has been redeposited (Site 688; Fig. 1). Organic-carbon-rich diatomaceous oozes and muds accumulated at both sites throughout the Pleistocene to Holocene, but differences in facies, in accumulation rates, and in the diagenetic boundary conditions of these coeval sediment sequences create differences in the paragenesis of diagenetic minerals and in the extent of organic-matter degradation by sulfate reduction. Older sediments (upper Miocene to Pleistocene at Site 680, Eocene to Pliocene at Site 688) are less organic-carbon-rich, contain more clastic components, and are coarser-grained at 


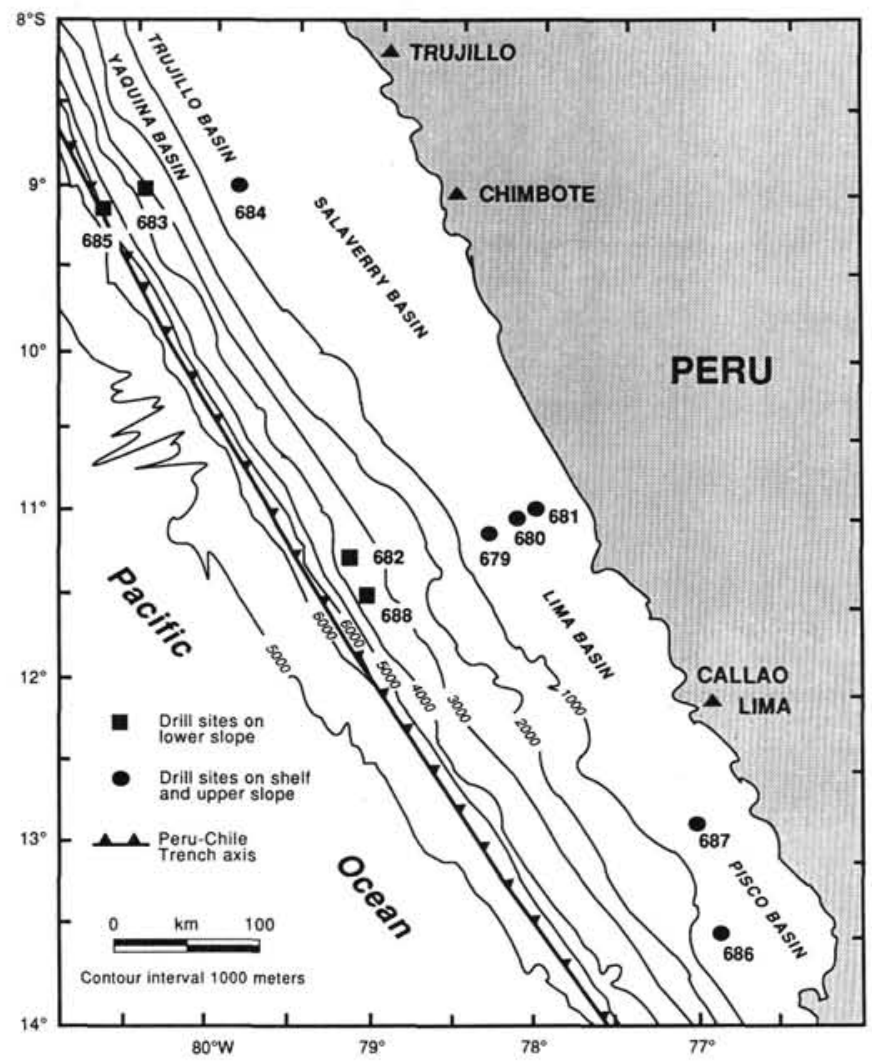

Figure 1. Location of Leg 112 drill sites offshore Peru with morphology and location of major forearc basins.

both sites; analysis of the carbon to sulfur relationship in the deeper parts of both sections might be suitable for evaluating the influences of physical properties and the peculiar hydrographic situation in the subsurface (see below) on diagenetic mineral formation. Because of problems with assessing $\mathrm{C} / \mathrm{S}$ ratios in organic-lean sediments and because of different ages for the clastic intervals at both sites, we decided to concentrate this investigation on the Quaternary sections of lithologic Units I at Sites 680 and 688 . We would like to point out, however, that TRS concentrations appeared inordinately high in the organic-lean sands and muds of both sites, and resulted in $\mathrm{C} / \mathrm{S}$ ratios that were frequently below unity. This may indicate that increased permeability creates favorable conditions for pyrite precipitation at sites of enhanced lateral fluid migration.

Site 680 (Figs. 1 and 2) is located in a water depth of $250 \mathrm{~m}$ in the center of a lens-shaped accumulation of organic-carbonrich upwelling sediments. Lithologic Units I and II ( 0.0 to 56.5 mbsf) are composed of foraminifer-bearing diatomaceous mud and ooze having alternating laminated and massive intervals; the sedimentation rate of Units I and II is approximately 55 $\mathrm{m} / \mathrm{m}$.y. Unit III (56.5 to $195.5 \mathrm{mbsf}$ ) is composed of sand, phosphatic sand, and mud. Laminated and diatomaceous intervals occur as intercalations of several meters thickness. Sedimentation rates in Unit II were about $30 \mathrm{~m} / \mathrm{m} . \mathrm{y}$. and exceeded $100 \mathrm{~m} / \mathrm{m} . \mathrm{y}$. in the lower Unit III (Suess, von Huene, et al., 1988).

A striking observation at Site 680 , which was similarly encountered at all other sites on the shelf offshore Peru, was the discovery of a hypersaline subsurface brine that pro- vided dissolved ions (all major ions except alkalinity increase downhole; Kastner et al., this volume) to fuel continued, extreme diagenesis in the organic-carbon-rich sediments. After depletion of interstitial sulfate at approximately 50 mbsf, sulfate concentrations increased to values of 37.9 $\mathrm{mM} / \mathrm{dm}^{3}$ at $195.5 \mathrm{mbsf}$, thus driving bacterial sulfate reduction beyond its normal extent and creating unique diagenetic environments.

Site 688 (Figs. 1 and 3) is located on the lower slope seaward of Site 680 in a water depth of $3820 \mathrm{~m}$. The lithologic units recognized here record progressive subsidence of Site 688 since the Eocene. Lithologic Unit I (0.0$338.5 \mathrm{mbsf}$ ) is of Pleistocene age and is composed of bioturbated diatomaceous mud. Sediments between 82.2 and 570 mbsf were black, but changed color to olive-gray after a few minutes of exposure to air. This phenomenon was interpreted as indicating the presence of metastable iron monosulfide, an observation that agrees with the extremely high sedimentation rates of 100 to $350 \mathrm{~m} / \mathrm{m}$.y. and the concomitant early depletion of sulfate in sediments having high iron contents (Berner, 1974). Upwelling-related sedimentation of diatomaceous ooze and mud is recorded since the early Miocene in lithologic Unit II (338.5 - $593.0 \mathrm{mbsf})$, which was deposited at rates of 10 to $50 \mathrm{~m} / \mathrm{m}$.y. Lower to middle Eocene opal-free calcareous and clastic rocks of Unit III make up the remainder of the recovered section below a pronounced unconformity at the base of Unit II. Details on the chemical composition and origin of the unusual interstitial waters at Site 688 are presented by Kastner et al. (this volume).

\section{MATERIALS AND METHODS}

Samples $\left(10 \mathrm{~cm}^{3}\right)$ were taken from split cores on board the JOIDES Resolution based on a routine sample spacing of usually less than $3 \mathrm{~m}$ in the case of Hole $680 \mathrm{~A}, 10 \mathrm{~m}$ in the case of Hole $688 \mathrm{~A}$, and much farther spaced in the clastic sediments low in organic carbon of Hole $688 \mathrm{E}$ (Tables 1 and 2). The samples were dried immediately in a freeze dryer, and then ground in an agate mortar. Calcium carbonate $\left(\mathrm{CaCO}_{3}\right)$ was determined using a Coulometrics $\mathrm{CaCO}_{3}$ analyzer after acid treatment with $2 \mathrm{~N} \mathrm{HCl}$. Organic carbon was determined with the TOC module of two different Rock-Eval pyrolysis instruments (Delsi Nermag): samples from Hole 680 were run on the shipboard instrument, and samples from Site 688 in a shore-based laboratory (Texaco, Houston). Both instruments were standardized using the standard material provided by Delsi. This procedure allowed us to establish the thermal maturity and state of preservation of the organic material in the samples by interpreting the hydrocarbon and carbon dioxide yields during pyrolysis, and by measuring the temperature of maximum hydrocarbon release during cracking of kerogen (or kerogen precursors). For the Rock-Eval technique, the reader should refer to Espitalié et al. (1985), Katz (1983), and Peters (1986), who also outline some pitfalls and precautions necessary when interpreting pyrolysis data from immature sediments. We found the method satisfactory for preliminary classification and evaluation of the state of degradation of organic matter in organic-rich ( $>2$ wt.\% TOC) immature sediments (Morse et al., unpublished data; Pratt et al., 1986).

The method for determining abundances of inorganic TRS is after Zhabina and Volkov (1978), as modified by Canfield et al. (1986). In brief, $\mathrm{H}_{2} \mathrm{~S}$ from reductive decomposition of sulfide by a $\mathrm{Cr}$ (II) solution in concentrated $\mathrm{HCl}$ is titrated with $\mathrm{PbClO}_{4}^{-}$, and the end point determined with a silver sulfide 


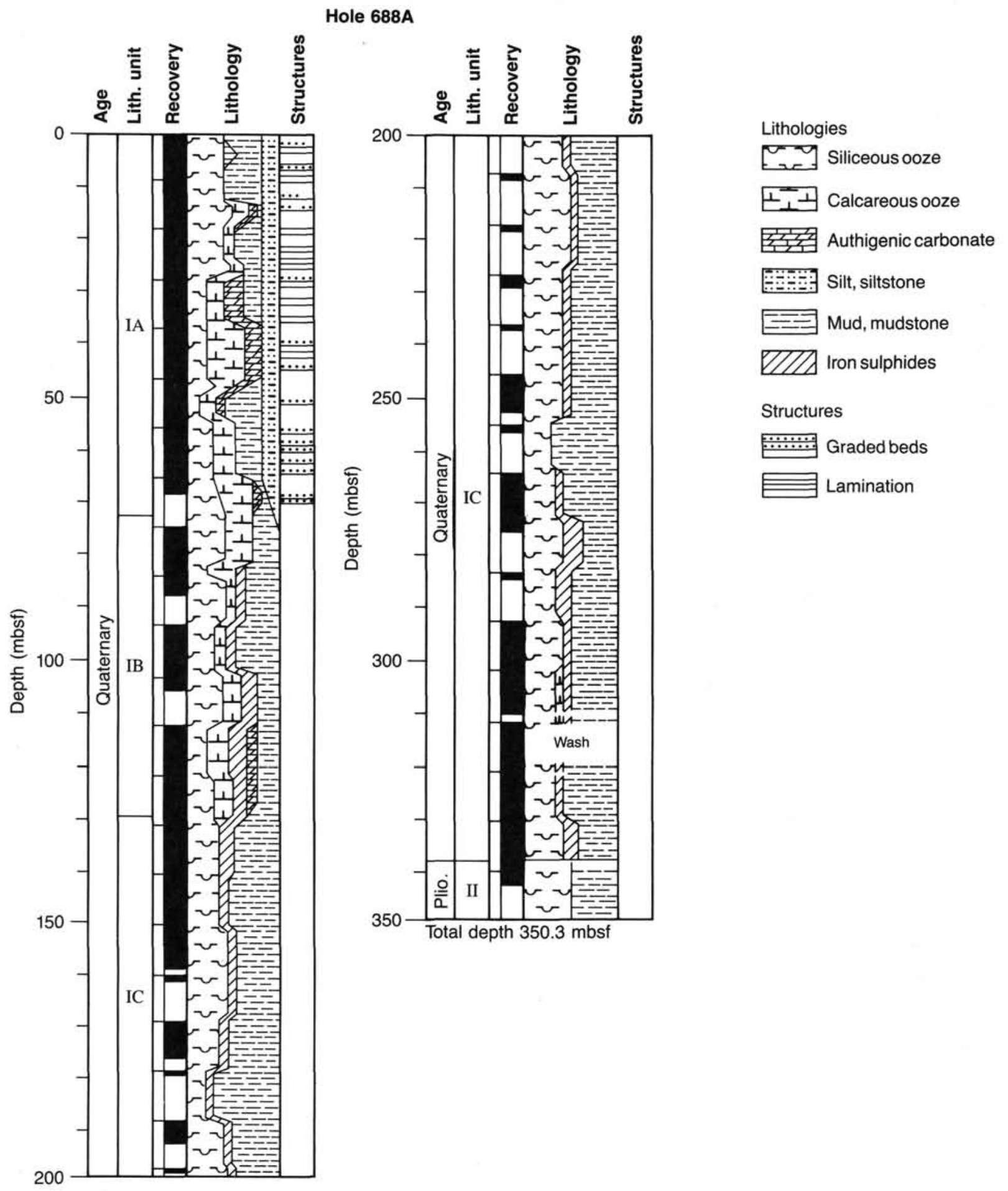

Figure 2. Lithologic summary of section recovered at Site 680 .

reference electrode. Attempts to measure iron monosulfide (acid volatile sulfur, AVS) after digestion in cold $6 \mathrm{~N} \mathrm{HCl}$ (Westrich, 1983) failed, because AVS was not present above tne detection limit of the method $(4 \mu \mathrm{M} / \mathrm{g})$, even though we strongly suspect that it was present in some of the fresh samples. Consequently, we interpret TRS and pyrite-S as being equivalent. The "reactive" iron fraction is a widely used and often loosely defined term that describes the fraction of total iron that probably is available for participation in chemical reactions under early diagenetic conditions. Leaching procedures using citrate, dithionite, and $\mathrm{HCl}$ solutions of different strengths have been the most widely used to determine this fraction, but many other methods are also being used. Canfield (1988) conducted a careful study of the behavior of different iron phases and his results indicate that the citrate/dithionite method extracts all the major iron oxide phases, while it removes only minor lattice-bound iron from iron silicate minerals. One exception is the clay mineral 


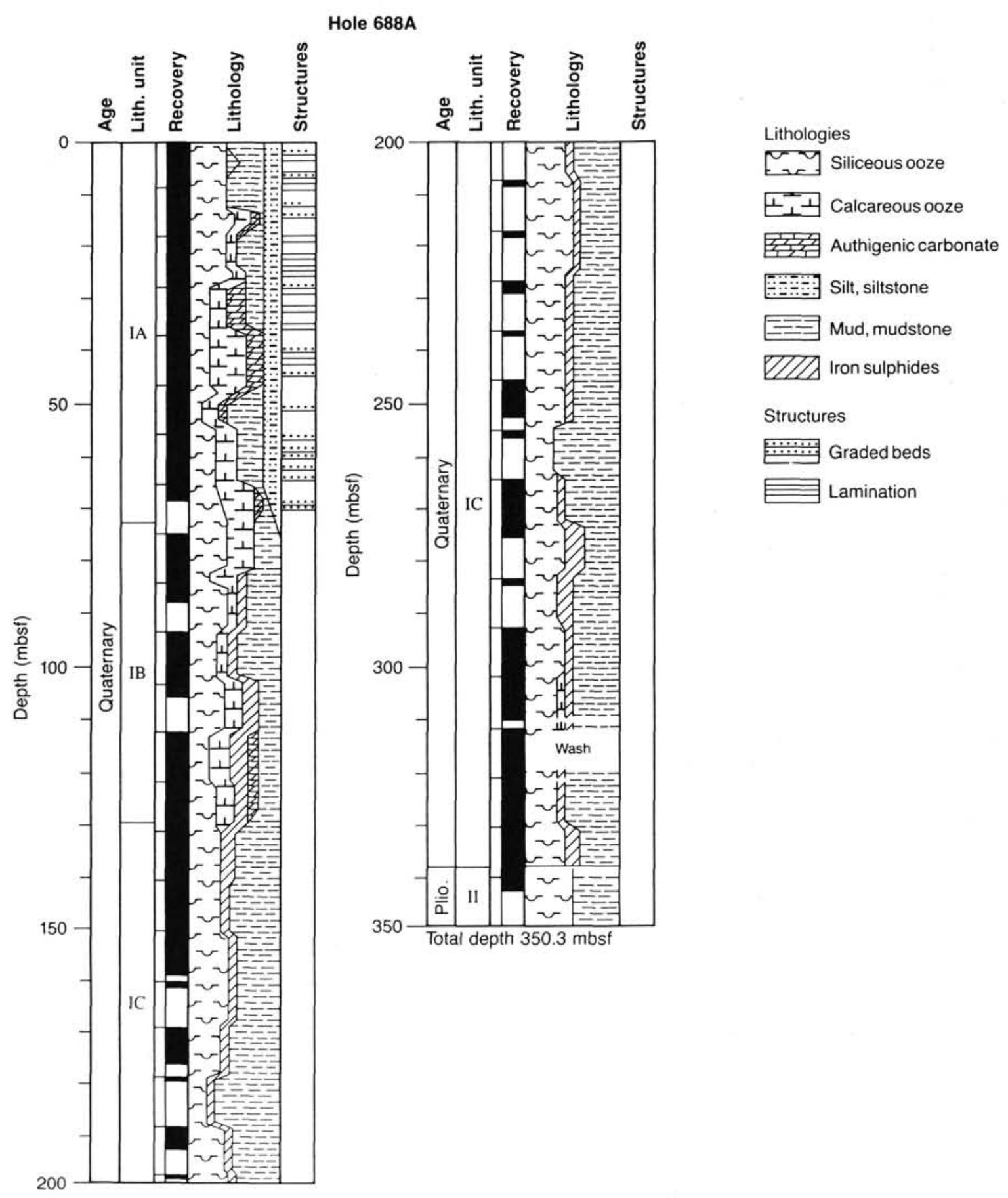

Figure 3. Lithologic summary of section recovered in Hole 688A.

nontronite. Huerta-Diaz and Morse (in press) compared the results for iron concentrations measured by both the citrate/ dithionite method and by leaching with $1 \mathrm{~N} \mathrm{HCl}$ in sediments having varying iron contents; they found remarkably good agreement between the two methods. Therefore, we have chosen the $1 \mathrm{~N} \mathrm{HCl}$-leachable iron to represent a reasonable approximation of the "reactive" iron fraction. The degree of pyritization (DOP) is given as

DOP $($ molar ratio $)=$ Pyrite $_{\mathrm{Fe}} /\left(\right.$ Pyrite $_{\mathrm{Fe}}+$ Reactive $\left._{\mathrm{Fe}}\right)$, where Pyrite Fe $_{\text {is }}$ well approximated as 0.5 TRS, based on the molar ratio of iron and sulfur in pyrite.

\section{RESULTS}

Concentrations of $\mathrm{CaCO}_{3}$, TOC, TRS, "reactive" iron (sol. Fe), total iron (von Breymann et al., this volume), DOP, $\mathrm{C} / \mathrm{S}$ weight ratios, and pyrolysis indexes are listed in Tables 1 and 2 . In the pyrolysis section of these tablets, $T_{\max }$ denotes the temperature of maximum hydrocarbon release from cracking of kerogen (or kerogen precursors), while $\mathrm{HI}$ and $\mathrm{OI}$ are the amounts of hydrocarbon and $\mathrm{CO}_{2}$, respectively, released from and normalized to the TOC content of the sample. These indexes are widely used to characterize the origin of organic matter in thermally mature sediments (Espitalié et al., 1985) 
Table 1. Results of chemical analyses of Site 680 sediments.

\begin{tabular}{|c|c|c|c|c|c|c|c|c|c|c|c|c|c|c|}
\hline $\begin{array}{l}\text { Core, section, interval } \\
(\mathrm{cm})\end{array}$ & $\begin{array}{l}\text { Depth } \\
\text { (mbsf) }\end{array}$ & $\begin{array}{l}\mathrm{CaCO}_{3} \\
\text { (wt. \%) }\end{array}$ & $\begin{array}{c}\text { TOC } \\
\text { (wt. \%) }\end{array}$ & $\begin{array}{l}\mathrm{T}_{\max } \\
\left({ }^{\circ} \mathrm{C}\right)\end{array}$ & $\mathrm{S}_{1}$ & $\begin{array}{l}\mathrm{S}_{2} \\
\mathrm{~g} \text { sedime }\end{array}$ & $S_{3}$ & HI & OI & $\begin{array}{c}\text { TRS } \\
\text { (wt. \%) }\end{array}$ & $\begin{array}{l}\text { Sol. Fe } \\
\text { (wt. \%) }\end{array}$ & $\begin{array}{l}\text { Total Fe } \\
\text { (wt. \%) }\end{array}$ & DOP & $\begin{array}{c}\mathrm{C} / \mathrm{S} \\
\text { (Ratio) }\end{array}$ \\
\hline $112-680 \mathrm{~A}-1 \mathrm{H}-2,25-26$ & 1.75 & n.d. & 2.18 & 403 & 1.24 & 7.54 & 3.19 & 345 & 146 & n.d. & n.d. & n.d. & n.d. & n.d. \\
\hline $1 \mathrm{H}-2,89-90$ & 2.40 & 0.75 & 12.42 & 399 & 25.25 & 92.17 & 34.12 & 742 & 274 & 0.77 & 0.12 & 1.93 & 0.85 & 16.1 \\
\hline $1 \mathrm{H}-3,25-26$ & 3.25 & 5.58 & 5.20 & 393 & 4.19 & 21.94 & 4.99 & 421 & 95 & n.d. & n.d. & n.d. & n.d. & n.d. \\
\hline $1 \mathrm{H}-4,25-26$ & 4.75 & 4.17 & 5.94 & 396 & 4.16 & 22.75 & 7.11 & 382 & 119 & 0.87 & 0.10 & n.d. & 0.88 & 6.8 \\
\hline $1 \mathrm{H}-4,77-80$ & 5.27 & 0.50 & 6.89 & 394 & 6.09 & 25.61 & 6.07 & 371 & 88 & 0.63 & 0.13 & 2.17 & 0.81 & 10.9 \\
\hline $1 \mathrm{H}-4,88-90$ & 5.38 & 6.16 & 5.62 & 397 & 4.82 & 24.57 & 5.94 & 437 & 105 & 0.74 & n.d. & n.d. & n.d. & 7.6 \\
\hline $1 \mathrm{H}-5,25-26$ & 6.25 & 14.49 & 9.75 & 392 & 7.86 & 40.32 & 9.83 & 413 & 100 & 0.61 & 0.12 & n.d. & 0.81 & 16.0 \\
\hline $1 \mathrm{H}-5,81-83$ & 6.81 & 9.50 & 5.82 & 403 & 4.57 & 25.45 & 5.59 & 437 & 96 & 0.65 & n.d. & n.d. & n.d. & 9.0 \\
\hline $1 \mathrm{H}-6,25-26$ & 7.75 & 4.66 & 6.16 & 400 & 5.01 & 27.63 & 8.06 & 448 & 130 & 0.78 & 0.10 & n.d. & 0.87 & 7.9 \\
\hline $1 \mathrm{H}-6,37-39$ & 7.90 & 1.83 & n.d. & n.d. & n.d. & n.d. & n.d. & n.d. & n.d. & 0.78 & n.d. & 1.59 & n.d. & n.d. \\
\hline $2 \mathrm{H}-1,25-26$ & 8.55 & 13.08 & 4.64 & 394 & 2.99 & 18.89 & 4.12 & 407 & 88 & 0.67 & 0.08 & n.d. & 0.88 & 6.9 \\
\hline $2 \mathrm{H}-1,86-88$ & 9.16 & 12.00 & 5.01 & 406 & 4.79 & 26.39 & 6.42 & 526 & 128 & 0.84 & n.d. & 1.89 & n.d. & 6.0 \\
\hline $2 \mathrm{H}-2,25-26$ & 10.05 & 1.67 & 5.08 & 394 & 3.26 & 21.27 & 4.56 & 418 & 89 & 1.09 & n.d. & n.d. & n.d. & 4.7 \\
\hline $2 \mathrm{H}-2,96-98$ & 10.76 & 31.99 & 3.38 & 401 & 1.94 & 12.35 & 3.04 & 365 & 89 & 1.14 & 0.13 & 3.96 & 0.87 & 3.0 \\
\hline $2 \mathrm{H}-3,25-26$ & 11.55 & 2.42 & 8.83 & 392 & 6.55 & 37.05 & 7.55 & 419 & 85 & 0.84 & 0.10 & n.d. & 0.89 & 10.5 \\
\hline $2 \mathrm{H}-3,51-53$ & 11.81 & 0.58 & 6.86 & 390 & 6.59 & 34.51 & 5.97 & 503 & 87 & 0.94 & n.d. & 2.30 & n.d. & 7.3 \\
\hline $2 \mathrm{H}-4,25-26$ & 13.05 & 0.00 & 7.12 & 385 & 4.67 & 30.35 & 5.13 & 426 & 72 & 1.07 & 0.14 & n.d. & 0.87 & 6.7 \\
\hline $2 \mathrm{H}-4,56-58$ & 13.36 & 0.42 & 3.65 & 397 & 3.07 & 23.03 & 4.63 & 630 & 126 & 0.79 & n.d. & 2.52 & n.d. & 4.6 \\
\hline $2 \mathrm{H}-5,25-26$ & 14.55 & 11.83 & 2.94 & 414 & 1.88 & 11.79 & 2.88 & 401 & 97 & 0.92 & 0.10 & 2.50 & 0.89 & 3.2 \\
\hline $2 \mathrm{H}-6,25-26$ & 16.05 & 0.08 & 3.47 & 402 & 3.46 & 24.71 & 3.75 & 712 & 108 & 0.96 & 0.11 & 2.07 & 0.89 & 3.6 \\
\hline $2 \mathrm{H}-6,68-70$ & 16.38 & 0.33 & 3.16 & 406 & 2.63 & 23.89 & 3.52 & 756 & 111 & 1.21 & n.d. & 2.41 & n.d. & 2.6 \\
\hline $2 \mathrm{H}-6,77-80$ & 16.48 & 0.48 & 1.04 & 404 & 0.87 & 8.09 & 2.53 & 777 & 243 & 0.71 & 0.12 & n.d. & 0.84 & 1.5 \\
\hline $2 \mathrm{H}-7,25-26$ & 17.55 & 9.16 & 9.09 & 403 & 9.97 & 57.32 & 8.70 & 630 & 95 & 0.92 & n.d. & n.d. & n.d. & 9.9 \\
\hline $2 \mathrm{H}-7,44-46$ & 17.74 & 15.25 & 4.54 & 390 & 8.45 & 42.63 & 6.99 & 939 & 153 & 1.00 & 0.11 & 2.35 & 0.89 & 4.5 \\
\hline $3 \mathrm{H}-1,26-27$ & 18.05 & 9.00 & 2.95 & 412 & 1.31 & 8.37 & 2.44 & 285 & 83 & 0.91 & n.d. & n.d. & n.d. & 3.2 \\
\hline $3 \mathrm{H}-1,93-95$ & 18.80 & 14.74 & n.d. & n.d. & n.d. & n.d. & n.d. & n.d. & n.d. & 0.94 & 0.10 & 2.29 & 0.89 & n.d. \\
\hline $3 \mathrm{H}-2,26-27$ & 19.55 & 3.76 & 3.77 & 412 & 4.3 & 28.57 & 5.61 & 757 & 148 & 0.75 & n.d. & 1.42 & n.d. & 5.0 \\
\hline $3 \mathrm{H}-2,121-123$ & 20.46 & 0.25 & 3.96 & 402 & 5.83 & 35.02 & 6.50 & 884 & 164 & 0.74 & 0.10 & n.d. & 0.86 & 5.4 \\
\hline $3 \mathrm{H}-3,26-27$ & 21.05 & 6.33 & 1.28 & 428 & 0.28 & 3.79 & 1.53 & 296 & 119 & 0.36 & n.d. & n.d. & n.d. & 3.6 \\
\hline $3 \mathrm{H}-3,116-118$ & 21.96 & 10.75 & 7.26 & 400 & 8.45 & 42.10 & 8.69 & 585 & 120 & 0.96 & 0.10 & 2.06 & 0.89 & 7.6 \\
\hline $3 \mathrm{H}-4,26-27$ & 22.55 & 1.00 & 5.80 & 413 & 5.36 & 40.40 & 7.36 & 696 & 126 & 0.84 & n.d. & 1.36 & n.d. & 6.9 \\
\hline $3 \mathrm{H}-4,119-121$ & 23.49 & 0.67 & 8.42 & 386 & 6.62 & 26.58 & 5.18 & 315 & 11 & 1.20 & 0.12 & n.d. & 0.90 & 7.0 \\
\hline $3 \mathrm{H}-5,26-27$ & 24.05 & 0.00 & 2.81 & 406 & 2.49 & 17.03 & 2.56 & 606 & 91 & 1.21 & n.d. & n.d. & n.d. & 2.3 \\
\hline $3 \mathrm{H}-5,32-34$ & 24.12 & 3.17 & 4.07 & 404 & 1.17 & 8.79 & 2.84 & 215 & 69 & 1.01 & 0.13 & 2.57 & 0.87 & 4.0 \\
\hline $3 \mathrm{H}-6,26-27$ & 25.55 & 26.49 & 2.00 & 425 & 0.19 & 2.34 & 1.29 & 117 & 64 & 0.18 & n.d. & 1.82 & n.d. & 11.1 \\
\hline $3 \mathrm{H}-6,81-83$ & 26.11 & 0.17 & 7.37 & 412 & 4.46 & 48.58 & 7.26 & 659 & 98 & 0.73 & 0.09 & n.d. & 0.88 & 10.1 \\
\hline $3 \mathrm{H}-7,26-27$ & 27.05 & 18.16 & 4.17 & 403 & 4.15 & 28.51 & 6.36 & 683 & 152 & 0.77 & n.d. & 1.93 & n.d. & 5.4 \\
\hline $4 \mathrm{H}-1,25-26$ & 27.55 & 29.82 & 3.89 & 411 & 2.04 & 15.56 & 4.12 & 400 & 105 & 0.41 & 0.05 & 1.91 & 0.87 & 9.5 \\
\hline $4 \mathrm{H}-2,25-26$ & 29.05 & 27.66 & 5.70 & 407 & 5.04 & 42.34 & 4.49 & 742 & 78 & 0.63 & n.d. & 1.71 & n.d. & 9.0 \\
\hline $4 \mathrm{H}-3,25-26$ & 30.55 & 0.17 & 10.09 & 401 & 5.99 & 43.12 & 4.45 & 427 & 44 & 1.07 & 0.14 & 2.56 & 0.87 & 9.4 \\
\hline $4 \mathrm{H}-4,25-26$ & 32.05 & 0.67 & 7.35 & 399 & 5.45 & 35.59 & 4.75 & 484 & 64 & 0.92 & n.d. & 1.93 & n.d. & 8.0 \\
\hline $4 \mathrm{H}-5,25-26$ & 33.55 & 7.25 & 2.24 & 421 & 0.59 & 7.54 & 2.23 & 336 & 99 & 0.41 & 0.08 & 1.27 & 0.81 & 5.5 \\
\hline $4 \mathrm{H}-6,25-26$ & 35.05 & 20.66 & 2.88 & 413 & 1.79 & 15.38 & 3.33 & 534 & 115 & 0.62 & 0.11 & 1.84 & 0.84 & 4.6 \\
\hline $4 \mathrm{H}-7,25-26$ & 36.55 & 0.00 & 3.71 & 405 & 2.41 & 21.36 & 2.86 & 575 & 77 & 0.94 & n.d. & 2.33 & n.d. & 3.9 \\
\hline $5 \mathrm{H}-1,18-19$ & 36.98 & 4.83 & 4.72 & 398 & 3.1 & 22.71 & 3.07 & 481 & 65 & 0.91 & 0.12 & 2.10 & 0.87 & 5.2 \\
\hline $5 \mathrm{H}-2,18-19$ & 38.48 & 2.50 & 8.23 & 387 & 6.18 & 33.63 & 4.50 & 457 & 54 & 1.05 & n.d. & 2.10 & n.d. & 7.8 \\
\hline $5 \mathrm{H}-3,18-19$ & 39.98 & 0.92 & 3.26 & 402 & 1.7 & 12.45 & 2.17 & 381 & 66 & 0.77 & 0.22 & n.d. & 0.75 & 4.2 \\
\hline $5 \mathrm{H}-3,57-59$ & 40.40 & 7.33 & 10.16 & n.d. & n.d. & n.d. & n.d. & n.d. & n.d. & 1.29 & n.d. & 2.93 & n.d. & 7.9 \\
\hline $5 \mathrm{H}-4,18-19$ & 41.47 & 0.17 & 6.24 & 388 & 4.65 & 27.35 & 4.32 & 438 & 69 & 0.99 & 0.13 & 1.85 & 0.87 & 6.3 \\
\hline $5 \mathrm{H}-5,18-19$ & 42.96 & 2.17 & 5.44 & 396 & 2.98 & 26.40 & 4.37 & 485 & 80 & 0.98 & n.d. & 3.39 & n.d. & 5.6 \\
\hline $6 \mathrm{H}-1,18-19$ & 46.38 & 3.84 & 4.40 & 385 & 3.83 & 20.10 & 2.60 & 456 & 59 & 1.23 & 0.11 & 2.50 & 0.90 & 3.6 \\
\hline $7 \mathrm{H}-1,35-36$ & 56.15 & 0.42 & 3.68 & 387 & 3.32 & 16.65 & 2.36 & 452 & 64 & 0.73 & n.d. & 1.35 & n.d. & 5.0 \\
\hline $7 \mathrm{H}-2,35-36$ & 57.63 & 1.67 & 0.37 & 357 & 0.02 & 0.07 & 0.83 & 18 & 224 & 1.50 & n.d. & n.d. & n.d. & 0.2 \\
\hline $7 \mathrm{H}-2,80-82$ & 58.10 & 1.75 & 1.60 & n.d. & n.d. & n.d. & n.d. & n.d. & n.d. & 1.60 & n.d. & 3.81 & n.d. & 1.0 \\
\hline $7 \mathrm{H}-3,35-36$ & 59.14 & 6.75 & 2.09 & 329 & 0.02 & 0.10 & 0.70 & 55 & 388 & 1.81 & n.d. & 4.11 & n.d. & 1.2 \\
\hline $7 \mathrm{H}-4,35-36$ & 60.64 & 4.42 & 2.17 & 385 & 0.08 & 0.33 & 0.95 & n.d. & n.d. & 1.89 & 0.16 & 3.86 & 0.91 & 1.1 \\
\hline $7 \mathrm{H}-5,35-36$ & 62.13 & 3.67 & 2.74 & 335 & 0.11 & 0.41 & 0.88 & 141 & 303 & 1.94 & n.d. & 4.17 & n.d. & 1.4 \\
\hline $7 \mathrm{H}-6,35-36$ & 63.63 & n.d. & 2.16 & 384 & 0.13 & 0.69 & 0.61 & 222 & 196 & 1.86 & 0.16 & n.d. & 0.91 & 1.2 \\
\hline $8 \mathrm{H}-1,34-36$ & 65.65 & 2.45 & 2.71 & 389 & 0.23 & 1.10 & 1.25 & 169 & 192 & 1.80 & n.d. & 3.59 & n.d. & 1.5 \\
\hline $8 \mathrm{H}-2,34-36$ & 67.15 & 4.83 & 4.20 & 377 & 0.59 & 1.92 & 0.85 & 252 & 111 & 1.56 & n.d. & 2.87 & n.d. & 2.7 \\
\hline $8 \mathrm{H}-3,34-36$ & 68.65 & 1.36 & 5.02 & 387 & 1.17 & 4.77 & 1.30 & 309 & 84 & 1.81 & 0.17 & 3.40 & 0.90 & 2.8 \\
\hline $8 \mathrm{H}-4,34-36$ & 70.13 & 1.25 & 5.04 & 381 & 1.33 & 5.02 & 1.40 & 274 & 76 & 1.66 & n.d. & 3.16 & n.d. & 3.0 \\
\hline $8 \mathrm{H}-5,34-36$ & 71.66 & 0.42 & 6.13 & 383 & 1.8 & 6.37 & 1.44 & 326 & 73 & n.d. & 0.17 & 2.63 & n.d. & n.d. \\
\hline $8 H-6,34-36$ & 73.16 & 5.50 & n.d. & n.d. & n.d. & n.d. & n.d. & n.d. & n.d. & n.d. & n.d. & 2.68 & n.d. & n.d. \\
\hline $8 \mathrm{H}-7,34-36$ & 74.66 & 1.07 & 6.01 & n.d. & n.d. & n.d. & n.d. & n.d. & n.d. & n.d. & 0.16 & 3.46 & n.d. & n.d. \\
\hline $9 \mathrm{H}-1,34-36$ & 75.14 & 1.33 & 3.13 & n.d. & n.d. & n.d. & n.d. & n.d. & n.d. & n.d. & n.d. & 4.38 & n.d. & n.d. \\
\hline $9 \mathrm{H}-2,34-36$ & 76.64 & 0.25 & 3.65 & n.d. & n.d. & n.d. & n.d. & n.d. & n.d. & n.d. & 0.19 & 3.86 & n.d. & n.d. \\
\hline $9 \mathrm{H}-3,34-36$ & 78.14 & 0.83 & 6.97 & n.d. & n.d. & n.d. & n.d. & n.d. & n.d. & n.d. & n.d. & 3.73 & n.d. & n.d. \\
\hline
\end{tabular}


Table 2. Results of chemical analyses of sediments at Site 688.

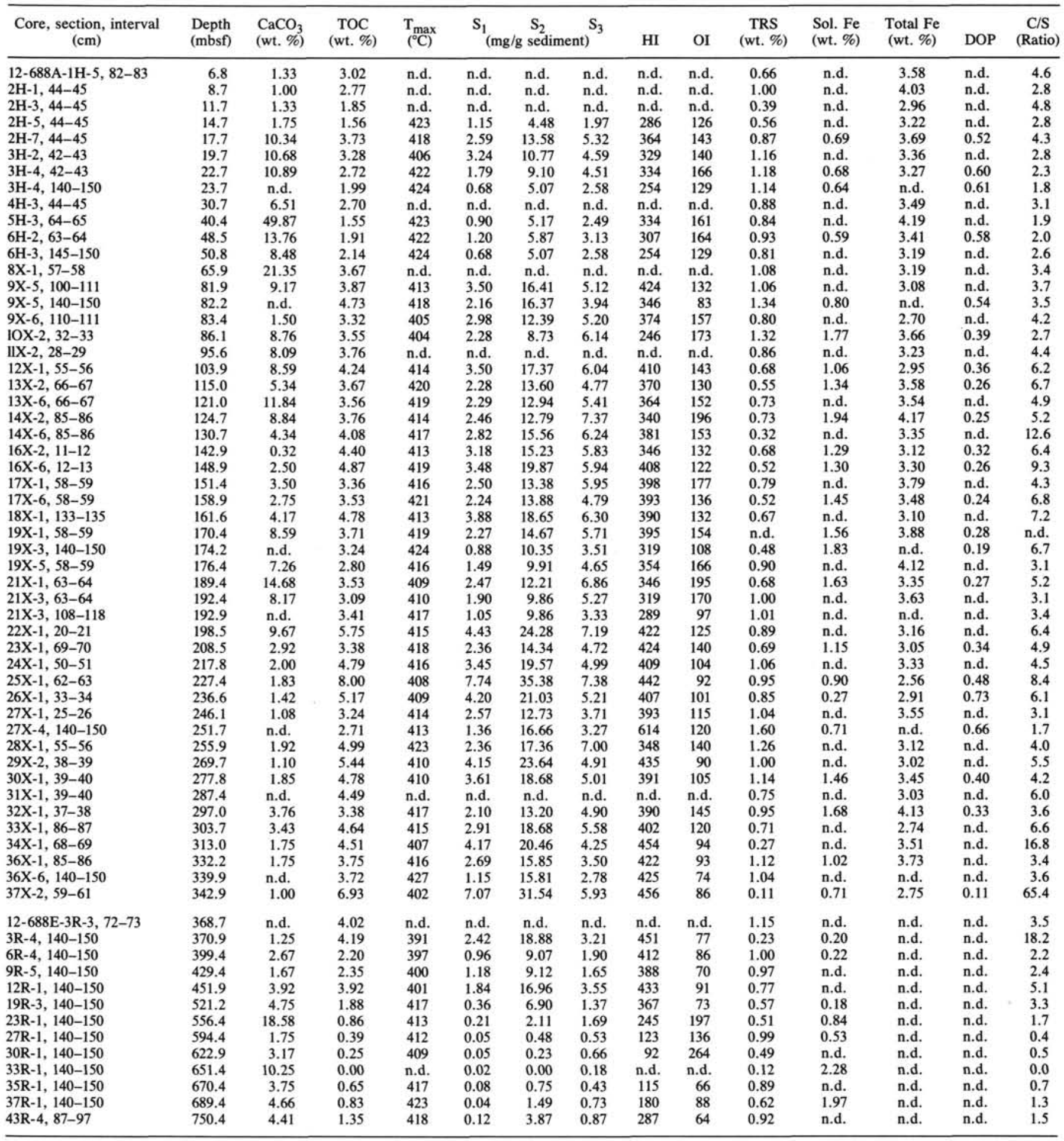

and are applicable to immature $\left(T_{\max }\right.$ below $\left.425^{\circ} \mathrm{C}\right)$ marine sediments with organic-carbon values above $2 \mathrm{wt} . \%$ as an indicator of provenance and state of degradation (e.g., Pratt et al., 1986).

The $T_{\max }$ values of pyrolytic hydrocarbon yield are below the lower threshold of the "oil window" $\left(425^{\circ} \mathrm{C}\right)$ and reflect thermal immaturity of the organic matter in both holes. TOC averages 5.2 wt.\% in Hole $680 \mathrm{~A}$. Values of $\mathrm{HI}$ in samples of Unit I of Hole $680 \mathrm{~A}$ (Fig. 4) are highly variable and reach up to 900 at low OI.
Such a high mean value of HI of 504, combined with a low average OI of 103 (Table 3) shows that the organic carbon deposited in Unit I at Site 680 is of marine origin (Espitalié et al., 1985 ) and contains abundant hydrocarbons and labile material. This observation is substantiated by analyses of labile particulate amino acids and sugars in comparable and coeval sediments of Site 681 (Seifert et al., this volume). Samples of Unit III have low hydrogen content and can be plotted in the area of terrestrial organic matter. 
Organic carbon in lithologic Unit I of Hole 688A (0-338.5 mbsf) was deposited during the Quaternary, seaward of Site 680 , and contains redeposited material from the shelf and upper slope. Both inorganic and organic geochemical characteristics of the sediments are different in lithologic Units I of the two sites. The variability in $\mathrm{HI}$ and $\mathrm{OI}$ is much less obvious in Hole $688 \mathrm{~A}$, which is confined to a narrow area between evolution paths of Type II and Type III organic matter. Pratt et al. (1986) found that HI and OI values of laminated and bioturbated interlayers in marine sediments differ significantly, because hydrogen loss during oxidation of marine organic matter in bioturbated layers results in a shift to lower HI and higher OI. Such oxidized marine organic matter is intermediate between the evolution paths of marine and terrestrial organic matter in a plot of $\mathrm{HI}$ and $\mathrm{OI}$, an effect that can be seen in samples of Hole 688A.

The elimination of substrate availability as a limiting factor for pyrite formation leaves sulfate and "reactive" iron limitations as possible reasons for the unexpected similarity in TRS concentrations in the sediments of the Peru margin. We plotted TOC, TRS, and the concentration of the "reactive" iron in Holes $680 \mathrm{~A}, 688 \mathrm{~A}$, and $688 \mathrm{E}$ vs. depth in Figures 5 and 6. Average values of TOC and TRS are $5.23 \mathrm{wt} . \%$ and 0.85 wt.\%, respectively, and the $\mathrm{C} / \mathrm{S}$ ratio of these averages is 6.1 . This is about twice the normal marine ratio of 2.8 . Because Site 680 is located on the shelf and is supplied with sulfatebearing hypersaline fluids in the subsurface, the deeper section exhibits interesting trends in $\mathrm{C} / \mathrm{S}$ ratio, sulfate gradient, and degree of pyritization. The latter value is high throughout the upper section to 56 mbsf (average for lithologic Unit I = 0.86 ), and exhaustion of "reactive"' iron is probably responsible for the high C/S ratios. Samples from lithologic Unit III, the sandy, clastic-dominated nearshore facies, have low TOC concentrations and the highest TRS content (average $=1.8$ wt.\%) of all samples studied (Fig. 5). In the three samples from this interval, the degree of pyritization is inordinately high (average $=0.91 \%$ ) and points to severe depletion of "reactive" iron. From the data on sulfate concentrations in pore waters given in Kastner et al. (this volume), it is obvious that sulfate reduction and $\mathrm{H}_{2} \mathrm{~S}$ production persists throughout the lithologic column at Site 680 . TRS concentrations in lithologic Unit III are higher than in the organic-rich mudstones above, even though organic carbon in the clastic sediments is low. Consequently, $\mathrm{C} / \mathrm{S}$ ratios are considerably lower than either in "normal" marine sediments (Sweeney, 1972 ), or in any of the other samples studied from this site. We propose that diffusion of $\mathrm{H}_{2} \mathrm{~S}$ and the "leaching" of iron bound in minerals of the clastic sequence of lithologic Unit III at Site 680 results in such high TRS concentrations. According to Mossman et al.'s results (this volume), dissolved sulfide in pore waters of Site 680 reaches $4.5 \mathrm{mM}$ at $47 \mathrm{mbsf}$ in Unit I and declines to $0.1 \mathrm{mM} / \mathrm{dm}^{3}$ at $72 \mathrm{mbsf}$ in Unit III. The concentration gradient implies downward diffusion of sulfide from the level of maximum concentration within the organiccarbon-rich upwelling deposits to the clastic sediments of Unit II. We propose that the clastic sequence, where iron concentrations are on average higher than in the biogenic sediments above, is the site of pyrite formation from migrated sulfide, in spite of exhaustion of the "reactive" iron measured during our leaching method. The source of iron in the clastic sequence is not identified, but possible sources are magnetic minerals, such as magnetite, that have not decomposed by our extraction procedure, or iron diffusing upward from deeper in the section.

In contrast to Hole $680 \mathrm{~A}$, the Quaternary sediments in Hole $688 \mathrm{~A}$ have a significantly lower degree of pyritization (average $=0.4$ ) and a ratio of average TOC to TRS of 4.3
(Table 3). Note that in this comparison the means of both TOC and the HI of samples from Units I of Holes $680 \mathrm{~A}$ and $688 \mathrm{~A}$ are significantly different (at a $95 \%$ confidence level in a Student t-test). TRS concentrations are not significantly different and average $0.86 \mathrm{wt} . \%$ and $0.85 \mathrm{wt} . \%$ in Hole $688 \mathrm{~A}$ and in Hole $680 \mathrm{~A}$, respectively. In a plot of TOC vs. TRS for lithologic Units $\mathrm{I}$ in Holes $680 \mathrm{~A}$ and $688 \mathrm{~A}$, samples with TOC $<3$ wt.\% follow the normal marine $C / S$ ratio of about 2.8, while samples containing more than 3 wt.\% TOC deviate systematically (Fig. 7). HIs of samples from lithologic Units I at both sites are not significantly correlated with TRS, and exhaustion of organic substrate cannot have been the limiting factor for pyrite formation at either of the two sites.

A plot of TRS vs. DOP demonstrates the limitation of pyrite formation by "reactive" iron in Hole 680A (Fig. 8), where no correlation is apparent between the two parameters. "Reactive" iron, even as measured by our rather gentle leaching method, may overestimate the availability of iron for pyrite formation by about $8 \%$, because the DOP never exceeds 0.92 even in the presence of interstitial sulfide in pore-water samples from this site (Mossmann et al., this volume). We conclude that "reactive" iron is limiting the formation of iron sulfide in sediments from the shelf site, where pyrite concentration averages $1.6 \mathrm{wt} . \%$ and ranges from 0.34 to $2.3 \mathrm{wt} . \%$. Iron in pyrite averages $0.74 \mathrm{wt} . \%$ (range of 0.15 to $1.06 \mathrm{wt} . \%$ ), which is, on average, $35 \%$ of total iron (Table 1).

DOP values correlate positively with TRS in the case of samples from Hole 688A (Fig. 8); one surprising observation is that an extrapolated DOP value of 0.9 resulted in TRS concentrations similar to those in the clastic Unit II of Hole $680 \mathrm{~A}$. Iron in pyrite (average $0.74 \mathrm{wt} \%$, range of 0.23 to 1.38 wt.\%) averages only $22 \%$ of total iron in sediments of Hole $688 \mathrm{~A}$ (Table 2). Pyrite contributes, on average, $1.6 \mathrm{wt} . \%$ to the sediment, similar to the value found in Hole $680 \mathrm{~A}$.

The preceding observations imply that, because abundant "reactive" iron and organic carbon are available for pyrite formation in samples from Hole $688 \mathrm{~A}$, a third factor limits the formation of pyrite here. This third factor may be limitation by sulfate. All three samples from the upper 40 mbsf of Hole $688 \mathrm{~A}$, where sulfate was found in interstitial waters, and all samples above 80 mbsf (outside the zone where iron monosulfide occurred) show DOP values above 0.5 , with roughly normal marine $\mathrm{C} / \mathrm{S}$ ratios. Even though traces of sulfate (tenths of millimoles) were reported at depths below 100 mbsf (Suess, von Huene, et al., 1988), these low sulfate values may be artifacts of sampling (M. Kastner, pers. comm., 1988).

\section{CONCLUSIONS}

Reduced-sulfur accumulation in organic-carbon-rich sediments from the continental slope and shelf offshore Peru is influenced by several factors, including iron limitation in the nearshore environment of Site 680 and exhaustion of sulfate in the rapidly accumulating continental slope sediments of Site 688. Concentration and quality of organic matter (frequently the dominant control for reduced sulfur accumulation) are high and do not limit bacterial sulfate reduction. $\mathrm{C} / \mathrm{S}$ ratios are mainly influenced by an upper concentration limit of approximately $1 \mathrm{wt} . \%$ TRS, and the variability of organic matter concentrations. Above $3 \mathrm{wt} . \%$ TOC, the amount of TRS does not increase, and $\mathrm{C} / \mathrm{S}$ ratios reach a maximum value of about 16 at both sites. Average TRS concentrations are the same in sediments of Pleistocene age at both sites, even though sedimentation rates are different by a factor of 2 . At Site 680 , 


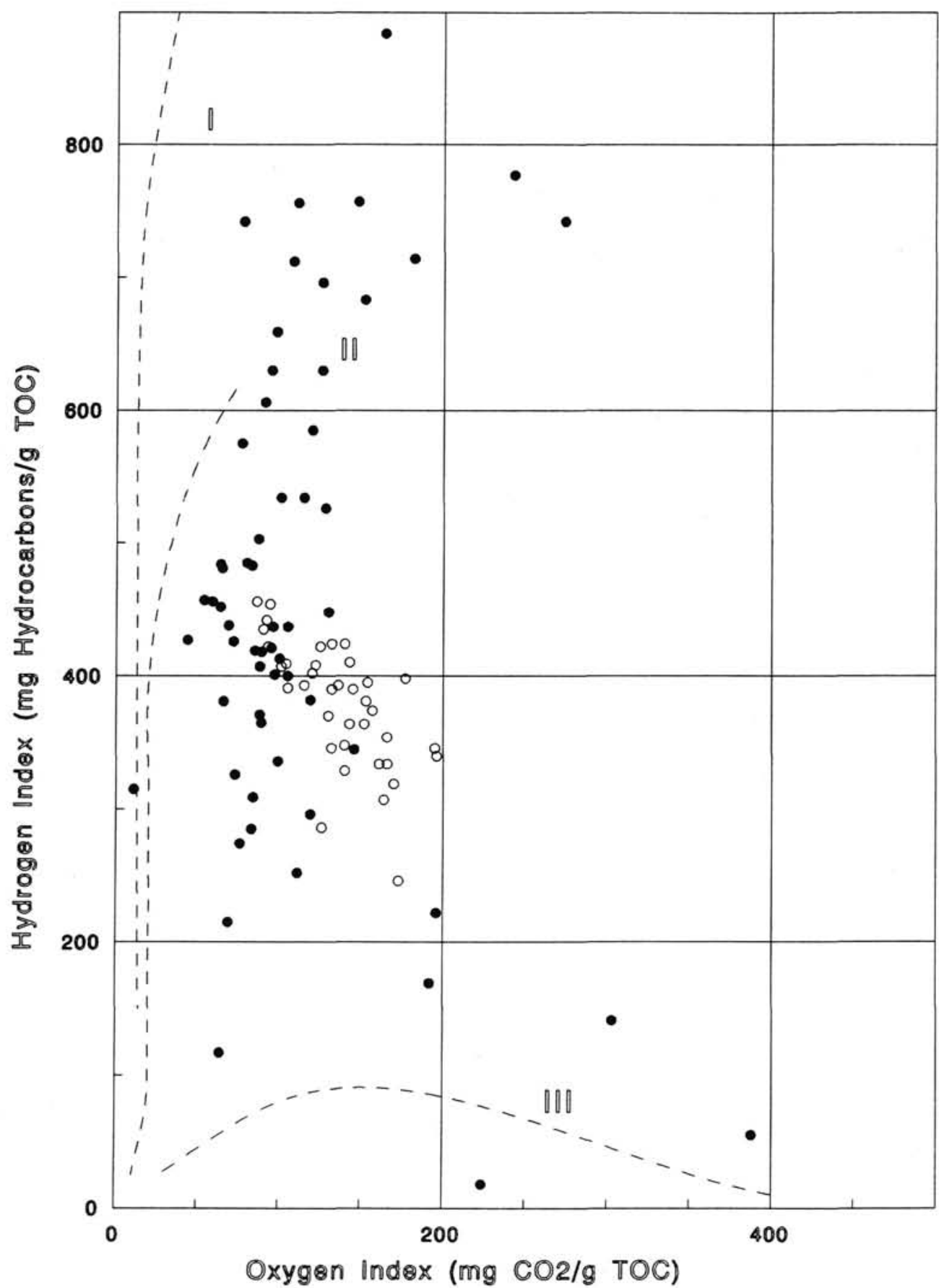

Figure 4. Van Krevelen-type diagram depicting the $\mathrm{OI}$ and $\mathrm{HI}$ of samples from Holes $680 \mathrm{~A}$ (closed circles) and $688 \mathrm{~A}$ (open circles). Evolution paths of kerogen Types I through III are denoted by dashed lines. Note the spread of $\mathrm{HI}$ for samples from Hole $680 \mathrm{~A}$, while samples from Hole 688 are well grouped and homogeneous.

the downward diffusion of sulfide, the subsurface supply of sulfate, and possibly the abundance of iron minerals that are not decomposed by our leaching technique lead to high TRS concentrations (up to $1.94 \mathrm{wt} . \%$ ) in organic-matter-lean sediments of lithologic Unit III.

\section{ACKNOWLEDGMENTS}

We gratefully acknowledge B. J. Katz's help (Texaco, Houston) with Rock-Eval analyses; the analytical assistance of Hege Jensvold and Saulwood Lin; reviews by M. Goldhaber, J. S. Leventhal, and W. Dean; and ODP for technical support. Funding for this program was provided by a grant from the U.S. Science Advisory Committee to K.-C. E.

\section{REFERENCES}

Berner, R. A., 1969. Migration of iron and sulfur within anaerobic sediments during early diagenesis. Am. J. Sci., 267:19-42.

1974. Iron sulfides in Pleistocene, deep, Black Sea sediments and their paleoceanographic significance. In Degens, E. T., and Ross, D. A. (Eds.), The Black Sea: Geology, Chemistry, and Biology. AAPG Mem., 20:524-531. 
1984. Sedimentary pyrite formation: an update. Geochim. Cosmochim. Acta, 48:605-615.

1985. Sulfate reduction, organic matter decomposition, and pyrite formation. Phil. Trans. R. Soc. London, 48:25-38.

Berner, R. A., and Raiswell, R., 1983. Burial of organic carbon and pyrite sulfur ion sediments over Phanerozoic time: a new theory. Geochim. Cosmochim. Acta, 47:855-862.

1984. C/S method for distinguishing freshwater from marine sedimentary rocks. Geology, 12:365-368.

Canfield, D. E., 1988. Sulfate reduction and the diagenesis of iron in anoxic marine sediments [Ph.D dissert.]. Yale Univ., New Haven.

Canfield, D. E., Raiswell, R., Westrich, J. T., Reeves, C. M., and Berner, R. A., 1986. The use of chromium reduction in the analysis of reduced inorganic sulfur in sediments and shale. Chem. Geol., 54:149-155.

Davison, W., Lishman, J. P., and Hilton, J., 1985. Formation of pyrite in freshwater sediments: implications for $\mathrm{C} / \mathrm{S}$ ratios. Geochim. Cosmochim. Acta., 49:1615-1620.

Espitalié, J., Deroo, G., and Marquis, F., 1985. La pyrolyse RockEval et ses applications. Rev. Inst. Français Pet., 40:563-579.

Huerta-Diaz, M. A., and Morse, J. W., in press. A quantitative method for determination of trace metal concentrations in sedimentary pyrite. Mar. Chem.

Katz, B. J., 1983. Limitations of "Rock-Eval" pyrolysis for typing organic matter. Organic Geochem., 4:195-199.

Leventhal, J. S., 1983. An interpretation of carbon and sulfur relationships in Black Sea sediments as indicators of environments of deposition. Geochim. Cosmochim. Acta., 47:133-137.

Peters, K. E., 1986. Guidelines for evaluating petroleum source rocks using programmed pyrolysis. AAPG Bull., 70:318-329.
Pratt, L. M., Claypool, G. E., and King, J. D., 1986. Geochemical imprint of depositional conditions on organic matter in laminatedbioturbated interbeds from fine-grained marine sequences. Mar. Geol., 70:67-84.

Raiswell, R., and Berner, R. A., 1985. Pyrite formation in euxinic and semi-euxinic sediments. Am. J. Sci., 285:710-724.

1987. Organic carbon losses during burial and thermal maturation of normal marine shales. Geology, 15:853-856.

Suess, E., von Huene, R., et al., 1988. Proc. ODP, Init. Repts., 112: College Station, TX (Ocean Drilling Program).

Sweeney, R. E., 1972. Pyritization during diagenesis in marine sediments [Ph.D dissert.]. Univ. of California, Los Angeles.

Westrich, J. T., 1983. The consequences and controls of bacterial sulfate reduction in marine sediments [Ph.D dissert.]. Yale Univ., New Haven.

Westrich, J. T., and Berner, R. A., 1984. The role of sedimentary organic matter in bacterial sulfate reduction: The $\mathrm{G}$ model tested. Limnol. Oceanogr., 29:236-249.

Zhabina, N. N., and Volkov, I. I., 1978. A method of determination of various sulfur compounds in sea sediments and rocks. In Krumbein, W. E. (Ed.), Environmental Biogeochemistry and Geomicrobiology, Vol. 3 - Methods, Metals and Assessment: Ann Arbor, MI (Ann Arbor Sci. Publ.), 735-746.

Date of initial receipt: 26 July 1988

Date of acceptance: 15 March 1989

Ms 112B-151

Table 3. Statistical evaluation of results of chemical analyses for samples from lithologic Unit I at both Sites 680 and 688.

\begin{tabular}{lccccccc}
\hline & N & Mean & Median & Std.dev. & SE & Min. & Max. \\
\hline Hole $680 A$ : & & & & & & \\
$\mathrm{CaCO}_{3}$ & 50 & 6.99 & 3.80 & 8.48 & 1.20 & 0.00 & 31.99 \\
TOC & 48 & 5.23 & 4.86 & 2.45 & 0.35 & 1.00 & 12.42 \\
$\mathrm{HI}$ & 48 & 504 & 452 & 174 & 25.1 & 117 & 939 \\
OI & 47 & 103 & 95 & 45 & 6.6 & 11 & 274 \\
TRS & 49 & 0.85 & 0.87 & 0.23 & 0.03 & 0.18 & 1.29 \\
DOP & 26 & 0.86 & 0.87 & 0.04 & 0.007 & 0.75 & 0.90 \\
Hole $688 A:$ & & & & & & \\
CaCO & 42 & 6.70 & 3.97 & 8.27 & 1.28 & 0.32 & 49.87 \\
TOC & 48 & 3.69 & 3.54 & 1.19 & 0.17 & 1.55 & 8.00 \\
HI & 41 & 371 & 374 & 65 & 10 & 246 & 614 \\
OI & 41 & 134 & 132 & 29 & 4 & 83 & 196 \\
TRS & 48 & 0.86 & 0.87 & 0.27 & 0.03 & 0.27 & 1.60 \\
DOP & 21 & 0.41 & 0.36 & 0.16 & 0.035 & 0.19 & 0.73 \\
\hline
\end{tabular}

TOC = total organic carbon; TRS = total reduced sulfur; $\mathrm{HI}=$ hydrogen index; $\mathrm{OI}=$ oxygen index; $\mathrm{DOP}=$ degree of pyritization; Std. dev. = standard deviation; $S E=$ standard error of the mean; Min. = minimum value; Max. = maximum value. 

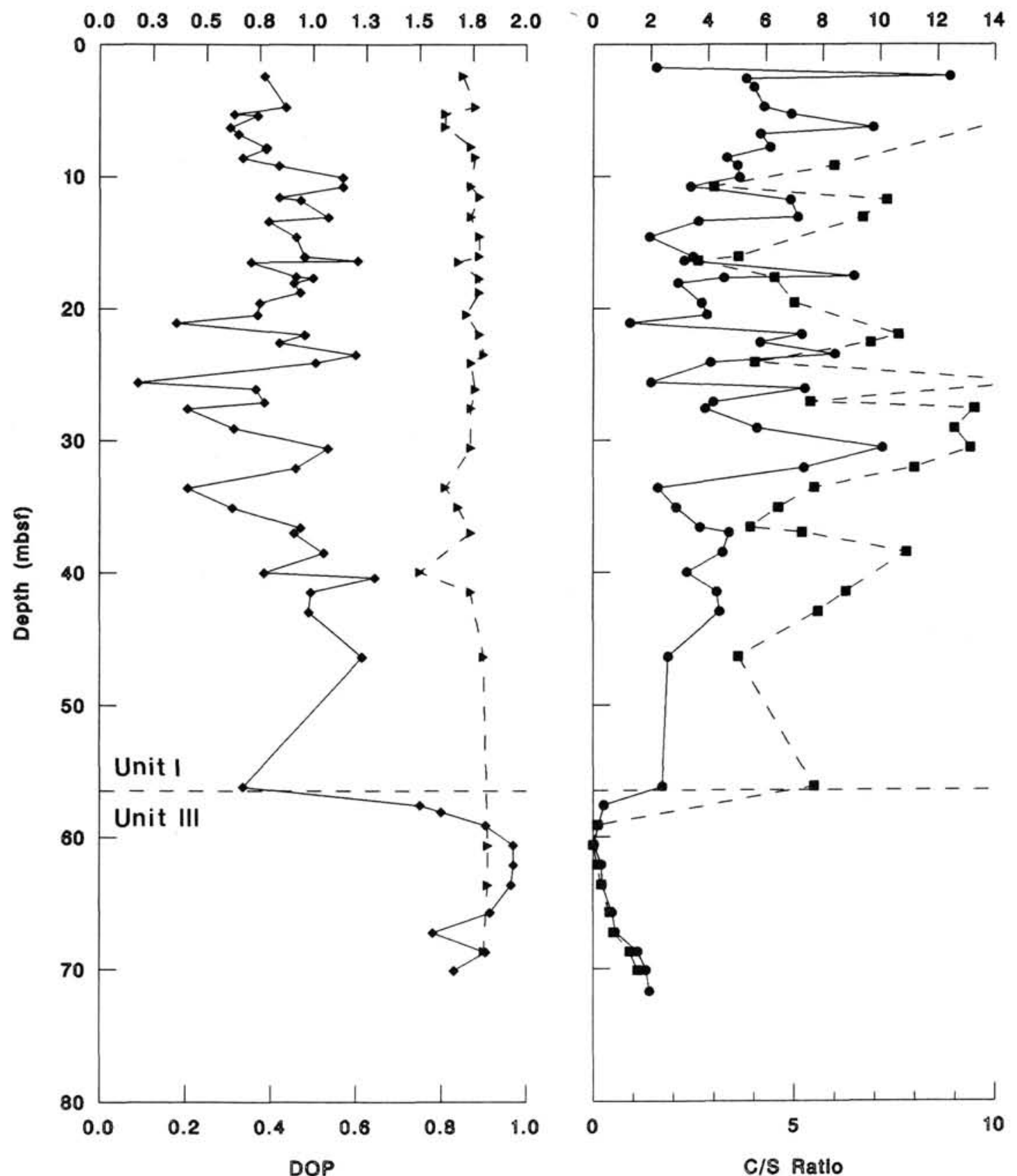

Figure 5. Downhole concentrations of TRS (solid line, diamonds), DOP (dashed line, triangles) TOC (solid line, closed circles), and C/S ratios (dashed line, squares) in Hole $680 \mathrm{~A}$. 

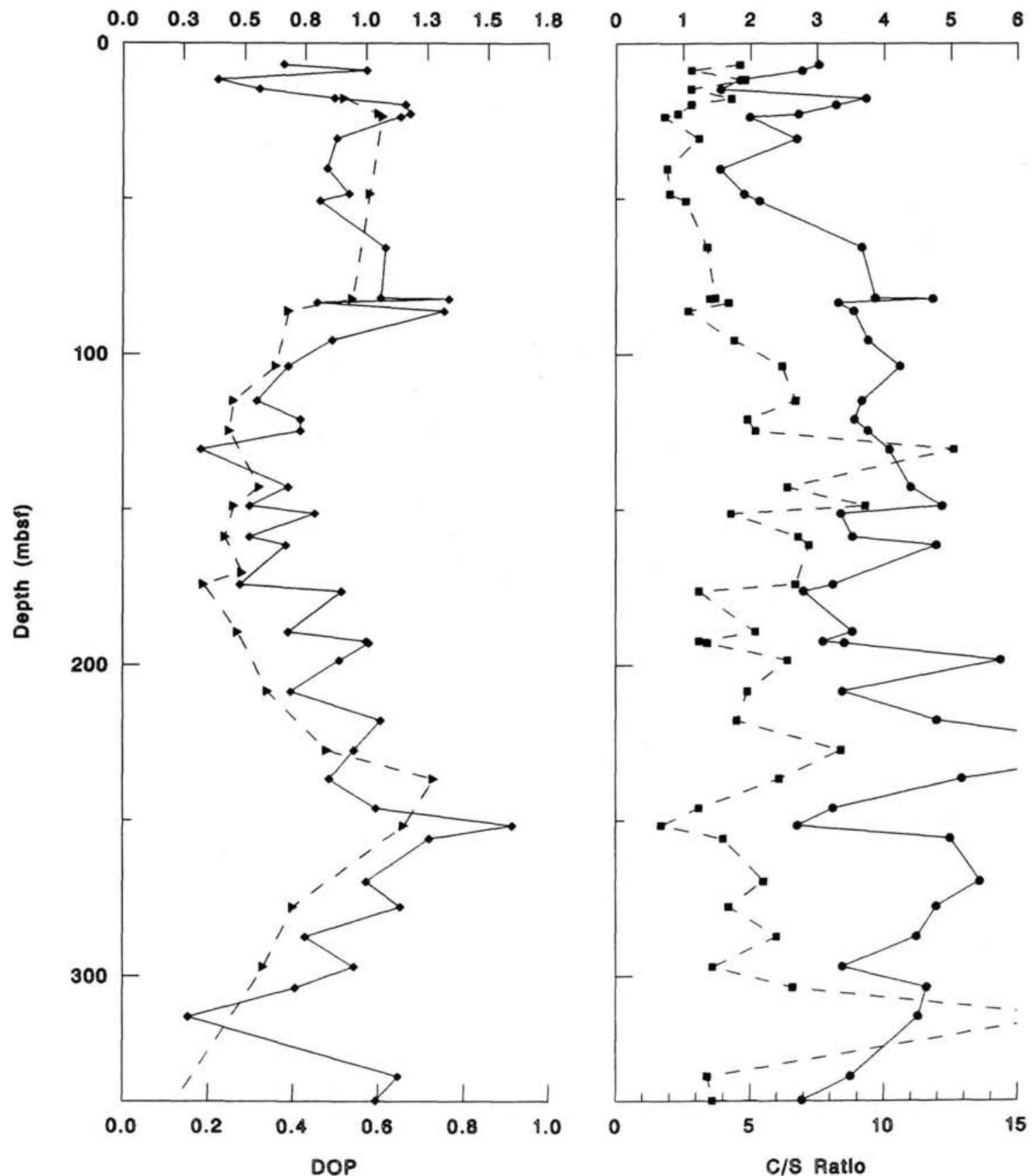

Figure 6. Downhole concentrations of TRS (solid line, diamonds), DOP (dashed line, triangles), TOC (solid line, filled circles), and $\mathrm{C} / \mathrm{S}$ ratios (dashed line, squares) in Hole 688A, lithologic Unit I. 


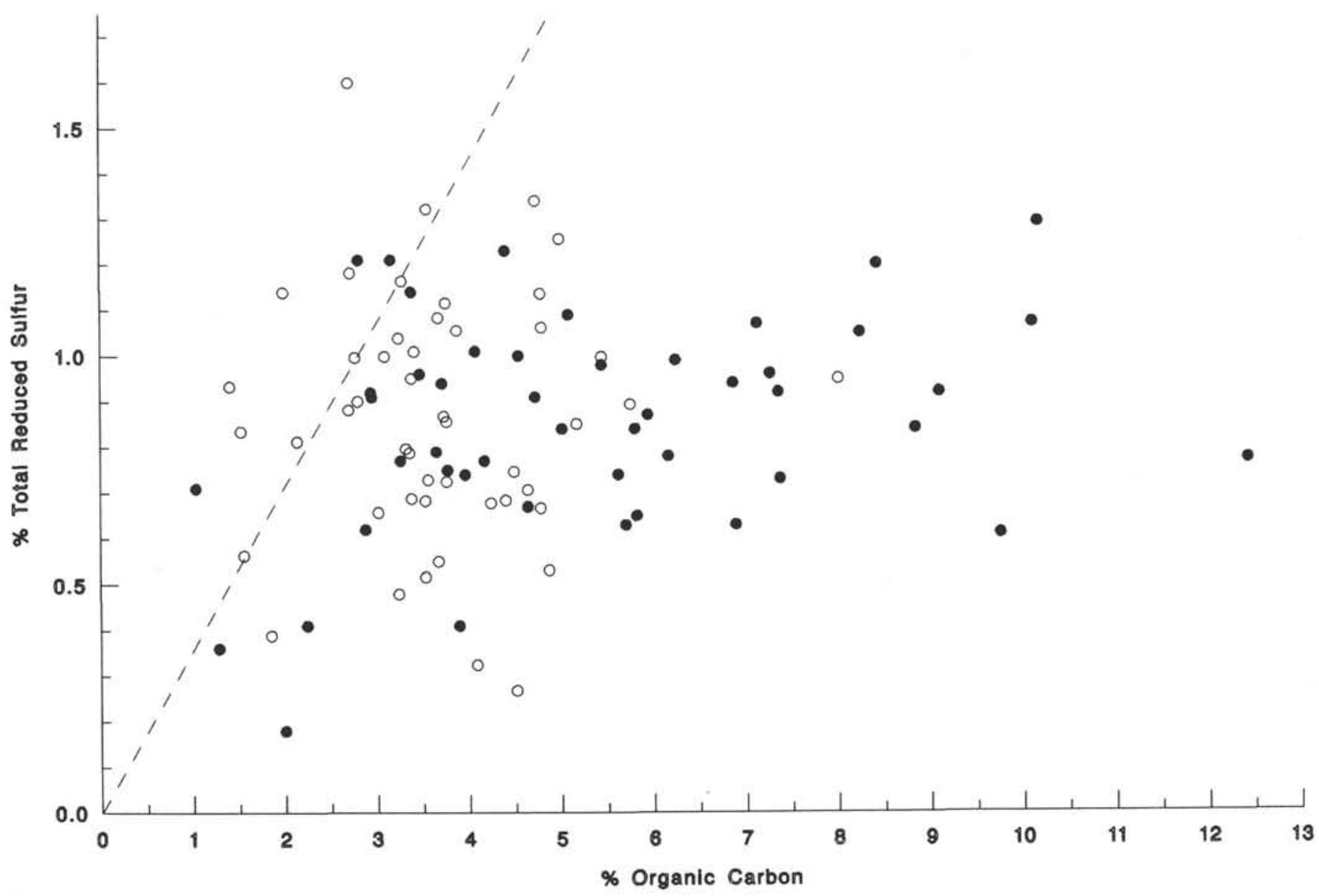

Figure 7. Plot of TOC vs. TRS for samples from Sites 680 (closed circles) and 688 (open circles) investigated here. The dashed line denotes a "normal" marine ratio of 2.8, as postulated by Sweeney (1972) and Berner (1984). Beyond 3 wt.\% TOC, the ratio of C/S deviates systematically from the ratio because TRS concentrations do not increase at increasing TOC. 


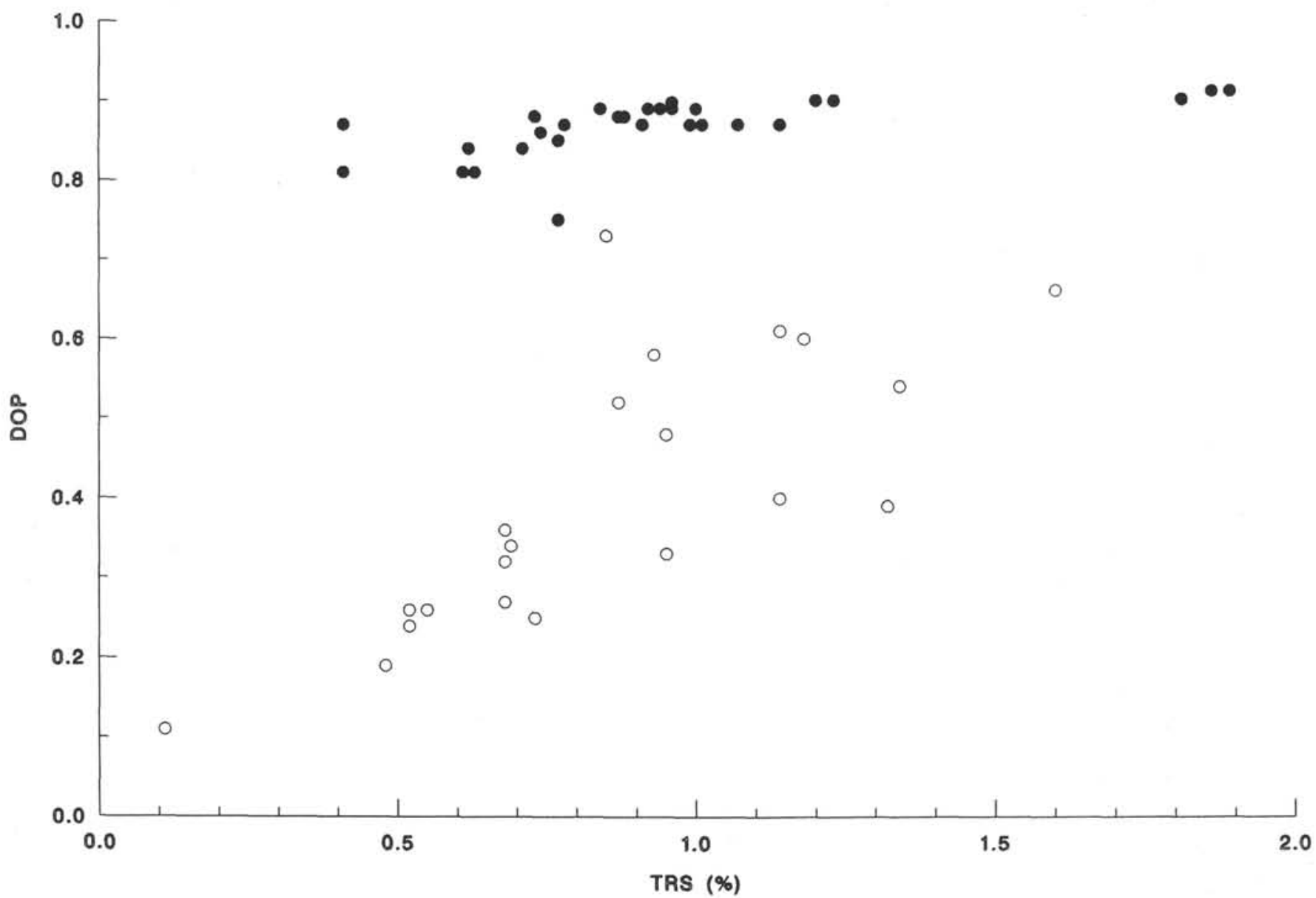

Figure 8. Plot of TRS vs. DOP for samples from Sites 680 (closed circles) and 688 (open circles). In Hole $680 \mathrm{~A}$, "reactive" iron is exhausted, and no correlation exists between TRS and DOP. Extrapolation of the relationship between TRS and DOP for samples from Hole 688A would result in TRS values of about $2 \mathrm{wt} . \%$ at DOP about 0.9 , the same values as those encountered in samples of Unit Il at Site 680 . Note that DOP is high and $\mathrm{C} / \mathrm{S}$ is low in samples from lithologic Unit IA of Hole 688A. 